\title{
12 \\ Organic residue analysis and the role of Lapita pottery
}

Mathieu Leclerc, Karine Taché, Stuart Bedford and Matthew Spriggs

The social practices related to food preparation and consumption are known to reveal important aspects of any culture, as resources are usually consumed not only for their taste and nutritional value but also for the significance they hold in specific contexts (Twiss 2012). Organic residue analysis represents a useful way to identify specific foods and relate them directly to artefacts. In contexts where containers are thought to bear a special value, directly identifying the content of pottery through organic residue analysis has the potential to highlight the status of different food resources within the community.

Such is the case with Lapita pottery, associated with the first human presence in Remote Oceania about 3000 years ago. Given the widespread sharing of intricate decorative motifs, highly organised designs and remarkable vessel forms across Vanuatu, New Caledonia, Fiji, Samoa and Tonga, archaeologists generally believe that the people who manufactured and used decorated Lapita pots attributed great cultural significance to their iconography (Chiu 2007; Mead 1975; Sand and Bedford 2010; Siorat 1990). Current models assume that the symbolic significance of these vessels was more important than their economic value. It has been suggested that dentate-stamped Lapita ceramics were used to promote, signal and convey information about the social status and power of Lapita communities, notably in the contexts of special events and/or ceremonies, such as funerals or feasts for example (Best 2002; Chiu 2007; Spriggs 2003; Terrell and Welsch 1997). The archaeological record shows that generally Lapita occupations have been relatively short-lived (200 years maximum) and quickly followed by the emergence of distinctive regional decorative styles, perhaps signalling the decreased significance of Lapita pottery following the disintegration of a shared cultural system.

If largely accepted, the idea that dentate-stamped Lapita pottery was involved in special symbolic/ ceremonial activities rather than prosaic domestic cooking is largely based on indirect contextual evidence. Our ongoing project is testing this hypothesis using organic data directly acquired from the vessels and reflecting their use. As a first step, the authors have recently analysed lipid residues absorbed within the walls of Lapita pottery from the cemetery site of Teouma in Vanuatu, in an effort to yield direct evidence of the food(s) associated with these decorated vessels (Leclerc et al. 2018). Besides confirming that food was indeed placed in the vessels, the homogenous lipid profiles and carbon isotopic values obtained in this pilot study suggests that similar food types or mixtures were placed in these vessels, potentially supporting their use for specialised functions. At this stage it is still premature to identify exactly which food(s) are associated with decorated Lapita pottery, but additional analyses of archaeological material and food items are currently being undertaken to shed further light on this question. Ultimately, by identifying the content of Lapita pottery, we wish to better understand the social value of various food items. 
This chapter aims to develop a few core concepts that are essential in order to reach this level of interpretation. The theoretical framework on which these interpretations will be based and more specifically the concept of highly valued food will be introduced. The implications of this framework and the relevance of organic residue analysis as opposed to other approaches to understand 3000-year-old behaviours will also be debated. Lastly, a review of the food items most likely to be found in Lapita pottery will be presented based on archaeological and environmental data.

\section{On the social role of highly valued food}

It has long been emphasised by anthropological studies that food acts as a social indicator in addition to its obvious nutritional values (Appadurai 1981; Ashley et al. 2004; Gumerman 1997; Mintz and Du Bois 2002). Because food is inherently interwoven with social habits and social structure (Atalay and Hastorf 2006; Bourdieu 1990), it represents a unique medium to convey social information about the status of consumers (Danforth 1999; Lévi-Strauss 1965). Food is not only a passive conveyer of messages but also contributes actively to the construction of the social structure (Ashley et al. 2004; Bourdieu 1998; Mintz 1996). Generally, it does so by carrying two contrasting types of social information: food can be used to homogenise a group and reinforce social bonds and/or to differentiate subgroups and establish social statuses (Appadurai 1981; Dietler 1996; van der Veen 2003). Both agendas can be promoted by the consumption of highly valued foods in special contexts and/or specific locations, either public or private (Curet and Pestle 2010; van der Veen 2003:406). For example, it is well established that religious rituals and feasts represent exceptional occasions and often involve the communal consumption of highly valued foods as a social display of power. These occasions also contribute in a particularly significant way in defining, strengthening and/or distinguishing social groups (Dietler 1996; Dietler and Hayden 2012; Hayden 2012; Wiessner 2012). In many societies, special events involving the communal and all-inclusive consumption of food are held to promote the unity of a group, in contrast with other feasts or rituals where access to certain types of foodstuffs is restricted (Hayden 2012; van der Veen 2003). In the latter case, exotic and/or foreign foods are often used as markers of social detachment (van der Veen 2003:415).

Highly valued food is a concept related to the culturally defined differentiation between staple food items and luxuries - that is, food with extra social value. This differentiation is based on several interrelated factors of varying importance depending on the situation, including the rarity, difficulty of preparation and acquisition (labour investment), exoticism, succulence and semiotic weight of the food (Appadurai 1986; Berry 1994; Curet and Pestle 2010; Dietler and Hayden 2012; Hayden 1996). On other occasions, quantity rather than qualitative traits appear to be more significant in revealing value, as reported for example by the ethnographic studies of De Garine (1976), Goody (1982) and Leach (2003) in African and East Polynesian communities where vast quantities of 'normal' food are used in ritual/feasting contexts.

Highly valued food items are thus specific to particular cultural contexts, and the status of any food item may also vary diachronically (van der Veen 2003:409-410). As a result, the criteria listed above do not always indicate high social value, as illustrated for instance by MacLean and Insoll's (2003) demonstration that exotic goods do not necessarily equate to luxury goods. Nevertheless, examples of exotic and scarce food items attributed high social value are numerous in the literature (see Ervynck et al. 2003) and several archaeologists have successfully reconstructed the value of food types based on their differential distribution and the presence of clear material correlates for feasting practices (e.g. Emery 2003; Kirch and O'Day 2003; LeFebvre and DeFrance 2014). 
For more recent time periods, other sources of data can be used to reconstruct the value of specific food items. In Polynesia, for example, certain foodstuffs are known to have been highly valued based on ethnohistorical and linguistic data (Kirch 2012; Kirch and O’Day 2003). In some cases, such information can be verified through independent lines of evidence. One isotopic study of human skeletons, for example, confirmed that fat and meaty food were highly valued amongst Polynesian groups in the recent past (around 750 to 300 BP) (Kinaston et al. 2013).

In the case of 3000-year-old Lapita pottery from Teouma, however, information about high-status food contained in proto-historic reports should not be adopted uncritically since it cannot be assumed that particular species kept the same symbolic roles over time. On one hand, ethnoarchaeological studies yield interesting data attesting to long-term continuity in humanthings relational systems and allowing for inspiring archaeological hypotheses and models through analogical inferences (Hamon 2016). However, it is rather naïve to suppose systematic persistence in behaviours over millennia, as similarities in material culture do not necessarily equate with diachronic continuity, particularly when comparing social groups separated by such long periods of time There are several examples of presumed ancestral traditions changing significantly through time (e.g. Cunningham and MacEachern 2016; Sillar and Ramón Joffré 2016) and even some cases where the social value of food items is known to have shifted from one extreme to the other, as in the case of oyster or deer in Europe (Grant 2002:20-22; van der Veen 2003:409-410 for other examples). Overall, 'it is far too easy to assume that the values assigned to particular foodstuffs in the past were the same as they are today' (Grant 2002:22). In Melanesia, several ethnoarchaeological studies have addressed the cultural importance of specific ingredients in a more recent past (e.g. Miles 1997; Wiessner 2012). While certainly relevant, the information provided by these sources should be considered with caution: 'That many practices ... look like ancient forms should not lead us to assume that they are in some way survivals from an ancient past' (Cunningham and MacEachern 2016:636).

In sum, we argue that ethnoarchaeological analogies are not sufficient to provide convincing interpretations on the use of Lapita pots dating back about 3000 BP. In Vanuatu, for example, the often assumed particular social status of pigs during early human occupation is solely based on excavations from much more recent sites (400 BP; Garanger 1972), as well as reports from the 16th-century Spanish navigator Quiros and contemporary kastom. To presume that pigs had a special status 3000 years ago based on its social importance in the last centuries appears as a weak inference. The absence of full circle tusks in Lapita sites could also be taken as counterevidence for the high status of pigs in ancient times, considering that tusked boars now represent social, political and economic capital in northern Vanuatu (Rodman 1996). It is true that pigs were part of a selective cultural complex and carried over long distances as they were introduced into the new territories colonised by Lapita peoples, but so were chicken, rats and a range of plant species. The other introduced species, animal and vegetal, could have equally been considered socially valuable. In light of this reasoning, we argue that every foodstuff available at the time of the Teouma cemetery could have had special value and potentially been placed in decorated Lapita pottery.

\section{Organic residue analysis of Lapita pottery}

In Melanesia, the archaeological study of food and resource exploitation is generally conducted through the prism of optimal foraging theory and behavioural ecology (e.g. Denham and Barton 2006; Hawkins 2015). While these approaches have some evident benefits, they provide little information about the cultural perception and social value of food items in human groups some 3000 years ago. Data from zooarchaeological assemblages and isotope studies have revealed that 
Lapita groups had a mixed diet composed of marine and terrestrial resources (e.g. Hawkins 2015; Kinaston, Buckley et al. 2014; Valentin et al. 2010), but they can hardly be used to examine the Lapita mindset regarding food. On the other hand, results from the organic residue analysis of Lapita and post-Lapita pottery will allow a better understanding of eating/serving habits and the social value of the food by directly relating food items to specific vessels.

The first wave of organic residue analysis on decorated Lapita vessels from Teouma supports the idea that these vessels were meant to hold a specific type of food (or mixture of food), tentatively supporting their specialised function (Leclerc et al. 2018). Indeed, lipid residues extracted from the decorated vessels were strikingly similar, which suggests that similar types of food were placed in every dentate-stamped container analysed. Specific food types were exclusively selected to be put in Lapita pottery, and it is plausible these particular foods held a particular cultural status. The homogeneity of molecular and isotopic values across all samples, despite variation in the forms and/or decorative motifs of the containers analysed, also contradicts any hypothesis that specific types of food could have been associated with specific forms of vessels. Interestingly, to date organic residue analysis strongly suggests that marine foods were not processed in Lapita pottery but the results do not allow us yet to distinguish between plants, non-ruminant animals and/or freshwater resources as the main components of the residues. Ongoing and future analyses will provide more information and precision regarding the food content of Lapita pottery, but in the meantime it is relevant to assess the archaeological and environmental context of these food types and on what grounds they may have been imbued with special or high social value.

\section{Lapita foods and vessels}

The scholarship on Lapita diet reveals that a generalist subsistence strategy combining marine and terrestrial broad-spectrum foraging, hunting and the cultivation of native and introduced plant species (so-called 'transported landscapes') characterises Lapita settlements (e.g. Crowther 2009; Hawkins 2015; Horrocks et al. 2014; Kinaston, Buckley et al. 2014; Valentin et al. 2010). It has also been confirmed directly by Leclerc et al. (2018), and indirectly by Crowther $(2006,2009)$ as well as Horrocks and Bedford (2005), that food was placed in Lapita decorated vessels. Whether the vessels were used to cook, prepare or serve the foods is however still uncertain, even if some technological features of decorated Lapita pottery suggest they are ill-designed for cooking (Ambrose 1997).

\section{Freshwater resources}

Keeping in mind that Teouma represents a colonising site and that raw materials used to manufacture some of the vessels have been traced back to New Caledonia, it is safe to assume that during their trip, the population that eventually settled on Efate and used Teouma as a cemetery must have been more accustomed to marine resources compared to freshwater species. To this day, very little research has been done on freshwater shellfish exploited by Lapita populations (cf. Szabó 2009) and remains from freshwater fish species are yet to be recovered from Lapita assemblages (Rintaro Ono, pers. comm. 2017). As opposed to the commonly available marine resources, the relative novelty, exoticism and rarity of the freshwater resources available on Efate must have been noticed by Lapita occupants. These traits correspond to some of the criteria usually associated with high-status food, as mentioned before. Consequently, it is plausible that freshwater resources were placed in decorated Lapita vessels and used in non-secular contexts at the cemetery. 


\section{Non-ruminant terrestrial animals}

Zooarchaeological remains recovered from various Lapita sites, including Teouma, confirm that terrestrial animal species were exploited by the occupants (Hawkins 2015; Kirch 2017; Sand 2010; Summerhayes et al. 2010). In fact, some of the animal populations were heavily impacted by human predation, to the point of extinction for species such as the tortoise, the crocodile and some bird species (Hawkins et al. 2016; Mead et al. 2002; Worthy et al. 2015). The idea, based on optimal foraging models, is that these abundant large animals were targeted first by Lapita newcomers because they represented prime, easy-to-catch preys providing vital amounts of calories and protein that greatly helped them settling in. Fruit bats (Pteropodidae) also represent a terrestrial species known to have been heavily exploited by Lapita communities (Bedford 2006; Kirch and Yen 1982; Worthy and Clark 2009). In addition to these native species, a number of domesticated and commensal animals (pigs, chicken, rats, but probably not dogs) were introduced into Remote Oceania by Lapita settlers (Anderson 2009; Hawkins 2015; Matisoo-Smith et al. 1998; Storey et al. 2008). The prime importance of these native and non-native terrestrial animals for the survival of the group during the earlier phase of occupation would have been acknowledged by Lapita peoples. It is plausible that such primary reliance raised the social status of these foods, thereby leading to their placement in highly decorated vessels and involvement in burial practices.

\section{Plant resources}

Considering that Teouma represents a colonising site (Bedford et al. 2010), it is argued that C3 plants were scarce during the early phase of Lapita occupation at Teouma. A number of C3 endemic plant species suitable for consumption were present in the archipelago when Lapita groups first arrived, although how rich the environment was is still a matter of debate (cf. Green 1991; Lebot and Sam in press; McClatchey 2012). It is generally argued that the bulk of edible plant resources at the time were limited to leafy vegetables, palms (including coconut, given that it was found in pre-human levels dated to 5000 BP on Aneityum-Spriggs 1984) and some tree crops such as Inocarpus fagifer, Canarium and Barringtonia (Walter and Sam 2002). With regards to newly introduced crops such as taro, yam and banana, it is safe to assume that their quantity must have been limited in the early stage of Lapita occupation, since time was required before the cultivation of introduced plant species thrived enough to make horticulture a viable and steady alternative to hunting and gathering. Overall, these conditions are in accordance with data obtained from faunal analysis and bulk isotopic studies of human bones, which indicate that plant resources, introduced or endemic, were not a major part of the diet in the early phase of the occupation.

Native C3 plants were most certainly less available than marine resources. Considering the significant quantity of marine remains recovered not only at Teouma but also on a majority of Lapita sites and the importance of maritime subsistence activity amongst Lapita people (Bedford 2006; Davidson et al. 2002; Kirch 1997:197-203; Szabó 2001), it is safe to assume that such resources were ubiquitous and commonly consumed at the time of Lapita occupations (Kinaston, Bedford et al. 2014; Kinaston, Buckley et al. 2014; Valentin et al. 2010).

The amount of work and effort necessary for the successful exploitation of plant resources would have been significant, especially for introduced crops. Consequently, the cost of acquisition would have been quite high for such foods. It has been demonstrated that these crops were introduced in Vanuatu as 'vegetative propagules', which are 'highly sensitive to salt sprays and drought' (Lebot and Sam in press). This implies that a considerable amount of care would have been required to protect these crops during the risky canoe trips over long distances. Lebot and Sam also highlight that the successful establishment of gardens by Lapita people colonising a new 
land was most likely the object of great and delicate attention. Moreover, it shows an intention to keep these crops available for the group, wherever they would establish themselves next. This demonstrates that these crops represented something worthwhile, to be preserved despite the effort, and regardless of whether this importance was based on a nutritional or cultural basis (or both).

During the first stages of occupation, the availability of these introduced resources must have been somewhat limited given the finite number of shoots introduced and the time required before gardens could be established. Months or years would have passed before the first occupants would have been able to collect the first harvests, and perhaps a decade before getting sufficient stock to supply a small community (Addison 2008; Lebot and Sam in press). Thereby, it is safe to claim that in the early days of settlement, introduced plant resources (such as taro, yam and banana) were labour-intensive to produce and relatively scarce. Overall, introduced plant species in Lapita communities fit many of the criteria associated with highly valued food. While this cannot be taken as a proof of the proposed scenario, the fact that starchy plants, including introduced species such as yam and taro, are nowadays very common in the diet of populations across Oceania (Pollock 1992; Walter and Lebot 2007) is consistent with the emulation process undergone by high-value and prestigious items, which typically become mainstream over time through a trickle-down effect (Grant 2002:20-22; van der Veen 2003:409-410).

\section{Conclusions}

Lapita people had access to a variety of food resources, several of which could have been placed in dentate-stamped vessels and possibly been highly valued. Relying solely on ethnohistorical sources to determine which resources could have been placed in Lapita pottery is not a reliable approach. Alternatively, organic residue analysis provides a means to look at research questions about Lapita foods and foodways from a refreshing perspective, potentially gaining new insights into the perceptions these people had of their food through its potential to identify the food content of decorated Lapita pottery. An initial pilot study suggests that specific foods were selected to be placed in Lapita pots, possibly confirming their specialised use. While molecular and isotopic values have allowed us to rule out marine resources as the content of the analysed samples, it is yet impossible to distinguish between plants, non-ruminant animals and/or freshwater resources as the main contributors of the residues. Here we demonstrated that all three could have been highly valued food. We are still at the dawn of our inquiry of Lapita foods and foodways using organic residues of dentate-stamped pottery, but it is clear from this chapter that interesting ideas can and have already been brought up. The outcomes are expanding our understanding of the Lapita mindset in regards to food beyond what has been possible so far.

Overall, the discussion presented in this chapter serves as a promising foundation on which upcoming results will build upon to provide new insights on Lapita people's cultural perceptions of food, and their use of decorated vessels in general. Ongoing and future analysis of archaeological ceramics and modern fats and oils will refine our interpretations and provide data that will allow us to address even broader research questions, such as comparing the content of plain and decorated ceramics, or testing whether the specialised use of Lapita pottery detected in our pilot also prevailed at other Lapita sites across Remote Oceania. 


\section{Acknowledgements}

Thanks to the Asia-Pacific Innovation Program for an Early Career Development Award that allowed Mathieu Leclerc to attend a workshop on organic residue analysis at Queens College, City University of New York, in February 2018 where fruitful discussions in relation to the paper were had. Thanks to Janine Billadello, Aida Romera and Evan Mann for assistance with laboratory work.

\section{References}

Addison, D. 2008. 'The changing role of irrigated Colocasia esculenta (taro) on Nuku Hiva, Marquesas Islands: From an essential element of colonization to an important risk-reduction strategy'. Asian Perspectives 47 (1):139-155. doi.org/10.1353/asi.2008.0008.

Ambrose, W. 1997. 'Contradictions in Lapita pottery, a composite clone'. Antiquity 71:525-538. doi.org/10.1017/S0003598X00085306.

Anderson, AJ. 2009. 'The rat and the octopus: Initial human colonization and the prehistoric introduction of domestic animals to Remote Oceania'. Biological Invasions 11 (7):1503-1519. doi. org/10.1007/s10530-008-9403-2.

Appadurai, A. 1981. 'Gastro-politics in Hindu South Asia'. American Ethnologist 8:494-511. doi.org/10.1525/ae.1981.8.3.02a00050.

Appadurai, A. 1986. 'Introduction: Commodities and the politics of value'. In The social life of things: Commodities in cultural perspective, edited by A Appadurai, 3-63. Cambridge: Cambridge University Press. doi.org/10.1017/CBO9780511819582.003.

Ashley, B, J Hollows, S Jones and B Taylor. 2004. Food and cultural studies. London: Routledge. doi.org/10.4324/9780203646915.

Atalay, S and CA Hastorf. 2006. 'Food, meals, and daily activities: Food habitus at Neolithic Çatalhöyük'. American Antiquity 71 (2):283-319. doi.org/10.2307/40035906.

Bedford, S. 2006. Pieces of the Vanuatu puzzle. Archaeology of the north, south and centre. Terra Australis 23. Canberra: ANU E Press. doi.org/10.22459/pvp.02.2007.

Bedford, S, M Spriggs, HR Buckley, F Valentin, R Regenvanu and M Abong. 2010. 'A cemetery of first settlement: The site of Teouma, South Efate, Vanuatu / Un cimetière de premier peuplement: Le site de Teouma, au sud d'Efaté, au Vanuatu'. In Lapita: Ancêtres Océaniens/Oceanic ancestors, edited by C Sand and S Bedford, 140-161. Paris: Musée du Quai Branly and Somogy Éditions d'Art.

Berry, CJ. 1994. The idea of luxury: A conceptual and historical investigation. Cambridge: Cambridge University Press. doi.org/10.1017/CBO9780511558368.

Best, S. 2002. Lapita: A view from the east. NZAA Monograph 24. Auckland: New Zealand Archaeological Association.

Bourdieu, P. 1990. The logic of practice. Cambridge: Polity Press.

Bourdieu, P. 1998. Practical reason. Palo Alto: Stanford University Press.

Chiu, S. 2007. 'Detailed analysis of Lapita face motifs: Case studies from Reef/Santa Cruz Lapita sites and New Caledonia Lapita site 13A'. In Oceanic explorations: Lapita and Western Pacific settlement, edited by S Bedford, C Sand and SP Connaughton, 241-264. Terra Australis 26. Canberra: ANU E Press. doi.org/10.26530/oapen_459398. 
Crowther, A. 2006. 'Taro processing and early Lapita pottery'. In Ancient starch research, edited by $\mathrm{R}$ Torrence and H Barton, 188. Walnut Creek: Left Coast Press.

Crowther, A. 2009. 'Investigating Lapita subsistence and pottery use through microscopic residues on ceramics: Methodological issues, feasibility and potential'. Unpublished $\mathrm{PhD}$ thesis, University of Queensland, Brisbane.

Cunningham, JJ and S MacEachern. 2016. 'Ethnoarchaeology as slow science'. World Archaeology 48 (5):628-641. doi.org/10.1080/00438243.2016.1260046.

Curet, AL and WJ Pestle. 2010. 'Identifying high-status foods in the archaeological record'. Journal of Anthropological Archaeology 29:413-431. doi.org/10.1016/j.jaa.2010.08.003.

Danforth, ME. 1999. 'Nutrition and politics in prehistory'. Annual Review of Anthropology 28:1-25. doi.org/10.1146/annurev.anthro.28.1.1.

Davidson, J, BF Leach and C Sand. 2002. 'Three thousand years of fishing in New Caledonia and the Loyalty Islands'. In Fifty years in the field: Essays in honour and celebration of R Shutler Jr's archaeological career, edited by S Bedford, C Sand and DV Burley, 153-164. Auckland: New Zealand Archaeological Association.

De Garine, IL. 1976. 'Food, tradition and prestige'. In Food, man, and society, edited by DN Walcher, N Kretchmer and HL Barnett, 150-173. New York: Plenum. doi.org/10.1007/978-1-4684-2298-6_10.

Denham, T and H Barton. 2006. 'The emergence of agriculture in New Guinea-A model of continuity from pre-existing foraging practices'. In Behavioral ecology and the transition to agriculture, edited by DJ Kennett and B Winterhalder, 237-264. Berkeley: University of California Press.

Dietler, M. 1996. 'Feasts and commensal politics in the political economy: Food, power and status in prehistoric Europe'. In Food and the status quest: An interdisciplinary perspective, edited by P Wiessner and W Schiefenhovel, 87-125. Providence: Berghahn.

Dietler, M and B Hayden. 2012. 'Digesting the feast: Good to eat, good to drink, good to think'. In Feasts: Archaeological and ethnographic perspectives on food, politics, and power, edited by M Dietler and B Hayden, 1-20. Tuscaloosa: University Alabama Press.

Emery, KF. 2003. 'The noble beast: Status and differential access to animals in the Maya world'. World Archaeology 34 (3):498-515. doi.org/10.1080/0043824021000026477.

Ervynck, A, W Van Neer, H Hüster-Plogmann and J Schibler. 2003. 'Beyond affluence: The zooarchaeology of luxury'. World Archaeology 34 (3):428-441. doi.org/10.1080/0043824021000026431.

Garanger, J. 1972. Archéologie des Nouvelles-Hébrides: Contribution à la connaissance des îles du Centre. Publications de la Société des Océanistes 30. Paris: Société des Océanistes, Musée de l'Homme. doi.org/10.4000/books.sdo.859.

Goody, J. 1982. Cooking, cuisine and class: A study in comparative sociology. Cambridge: Cambridge University Press. doi.org/10.1017/CBO9780511607745.

Grant, A. 2002. 'Food, status and social hierarchy'. In Consuming passions and patterns of consumption, edited by P Miracle and N Milner, 17-24. Cambridge: McDonald Institute for Archaeological Research.

Green, RC. 1991. 'Near and Remote Oceania-Disestablishing "Melanesia” in culture history'. In Man and a half: Essays in Pacific anthropology and ethnobiology in honour of Ralph Bulmer, edited by A Pawley, 491-502. Auckland: The Polynesian Society.

Gumerman, G. 1997. 'Food and complex societies'. Journal of Archaeological Method and Theory 4 (2):105-139. doi.org/10.1007/BF02428056. 
Hamon, C. 2016. 'Debates in ethnoarchaeology today: A new crisis of identity or the expression of a vibrant research strategy?’ World Archaeology 48 (5):700-704. doi.org/10.1080/00438243.2016. 1234409.

Hawkins, S. 2015. 'Human behavioural ecology, anthropogenic impact and subsistence change at the Teouma Lapita site, central Vanuatu, 3000-2500 BP'. Unpublished PhD thesis, The Australian National University, Canberra.

Hawkins, S, TH Worthy, S Bedford, M Spriggs, G Clark, G Irwin, S Best and P Kirch. 2016. 'Ancient tortoise hunting in the southwest Pacific'. Nature: Scientific Reports 6 (38317). doi.org/10.1038/ srep38317.

Hayden, B. 1996. 'Feasting in prehistoric and traditional societies'. In Food and the status quest: An interdisciplinary perspective, edited by P Wiessner and W Schiefenhovel, 127-147. Providence: Berghahn.

Hayden, B. 2012. 'Fabulous feasts: A prolegomenon to the importance of feasting'. In Feasts: Archaeological and ethnographic perspectives on food, politics and power, edited by M Dietler and B Hayden, 23-64. Tuscaloosa: University of Alabama Press.

Horrocks, M and S Bedford. 2005. 'Microfossil analysis of Lapita deposits in Vanuatu reveals introduced Araceae (aroids)'. Archaeology in Oceania 39:67-74. doi.org/10.1002/j.1834-4453.2005.tb00587.x.

Horrocks, M, MK Nieuwoudt, R Kinaston, HR Buckley and S Bedford. 2014. 'Microfossil and Fourier Transform InfraRed analyses of Lapita and post-Lapita human dental calculus from Vanuatu, Southwest Pacific'. Journal of the Royal Society of New Zealand 44 (1):17-33. doi.org/10.1080/03036758.2013.84 2177.

Kinaston, R, S Bedford, M Richards, S Hawkins, A Gray, K Jaouen, F Valentin and HR Buckley. 2014. 'Diet and human mobility from the Lapita to the early historic period on Uripiv Island, Northeast Malakula, Vanuatu'. PLoS ONE 9 (8):e104071. doi.org/10.1371/journal.pone.0104071.

Kinaston, RL, HR Buckley and A Gray. 2013. 'Diet and social status on Taumako, a Polynesian outlier in the southeastern Solomon Islands'. American Journal of Physical Anthropology 151:589-603. doi.org/10.1002/ajpa.22314.

Kinaston, R, HR Buckley, F Valentin, S Bedford, M Spriggs, S Hawkins and E Herrscher. 2014. 'Lapita diet in Remote Oceania: New stable isotope evidence from the 3000-year-old Teouma Site, Efate Island, Vanuatu'. PLoS ONE 9 (3):e90376. doi.org/10.1371/journal.pone.0090376.

Kirch, PV. 1997. The Lapita peoples: Ancestors of the Oceanic world. Cambridge, Massachusetts: Blackwell.

Kirch, PV. 2012. 'Polynesian feasting in ethnohistoric, ethnographic, and archaeological contexts'. In Feasts: Archaeological and ethnographic perspectives on food, politics, and power, edited by M Dietler and B Hayden, 168-184. Tuscaloosa: University Alabama Press.

Kirch, PV. 2017. On the road of the winds: An archaeological history of the Pacific Islands before European contact. Revised and expanded edition. Berkeley: University of California Press. doi.org/10.1002/ arco. 5168 .

Kirch, PV and SJ O'Day. 2003. 'New archaeological insights into food and status: A case study from precontact Hawaii’. World Archaeology 34 (3):484-497. doi.org/10.1080/0043824021000026468.

Kirch, PV and DE Yen. 1982. Tikopia: The prehistory and ecology of a Polynesian outlier. B.P. Bishop Museum Bulletin 238. Honolulu: Bishop Museum.

Leach, H. 2003. 'Did East Polynesians have a concept of luxury foods?' World Archaeology 34 (3):442-457. doi.org/10.1080/0043824021000026440. 
Lebot, V and C Sam. in press. 'Green desert or "all you can eat"? How diverse and edible was the flora of Vanuatu before human introductions?' In Debating Lapita: Distribution, chronology, society and subsistence, edited by S Bedford and M Spriggs. Canberra: ANU Press.

Leclerc, M, K Taché, S Bedford, M Spriggs, A Lucquin and OE Craig. 2018. 'The use of Lapita pottery: Results from the first analysis of lipid residues'. Journal of Archaeological Science: Reports 17:712-722. doi.org/10.1016/j.jasrep.2017.12.019.

LeFebvre, MJ and SD DeFrance. 2014. 'Guinea pigs in the Pre-Columbian West Indies'. Journal of Island \& Coastal Archaeology 9:16-44. doi.org/10.1080/15564894.2013.861545.

Lévi-Strauss, C. 1965. 'The culinary triangle'. Partisan Review 33:586-595.

MacLean, R and T Insoll. 2003. 'Archaeology, luxury and the exotic: The examples of Islamic Gao (Mali) and Bahrain'. World Archaeology 34 (3):558-570. doi.org/10.1080/0043824021000026512.

Matisoo-Smith, E, RM Roberts, GJ Irwin, JS Allen, D Penny and DM Lambert. 1998. 'Patterns of prehistoric human mobility revealed by mitochondrial DNA from the Pacific rat'. Proceedings from the National Academy of Sciences 95:15145-115150.

McClatchey, WC. 2012. 'Wild food plants of Remote Oceania'. Acta Societatis Botanicorum Poloniae 81:371-380. doi.org/10.5586/asbp.2012.034.

Mead, JI, DW Steadman, SH Bedford, CJ Bell and M Spriggs. 2002. 'New extinct Mekosuchine crocodile from Vanuatu, South Pacific'. Copeia 3:632-641. doi.org/10.1643/0045-8511(2002)002 [0632:NEMCFV]2.0.CO;2.

Mead, SM. 1975. 'The decorative system of the Lapita potters of Sigatoka, Fiji'. In The Lapita style of Fiji and its associations, edited by SM Mead, L Birks, H Birks and E Shaw, 19-43. Polynesian Society Memoir 38. Wellington: The Polynesian Society.

Miles, WFS. 1997. 'Pigs, politics and social change in Vanuatu'. Society and Animals 5 (2):155-167. doi.org/10.1163/156853097X00051.

Mintz, SW. 1996. Tasting food, tasting freedom. Boston: Beacon Press.

Mintz, SW and CM Du Bois. 2002. 'The anthropology of food and eating'. Annual review of Anthropology 31:99-119. doi.org/10.1146/annurev.anthro.32.032702.131011.

Pollock, NJ. 1992. These roots remain: Food habits in islands of the Central and Eastern Pacific since Western contact. Honolulu: University of Hawai'i Press.

Rodman, W. 1996. 'Pigs in paradise'. In Arts of Vanuatu, edited by J Bonnemaison, 158-168. Honolulu: University of Hawai'i Press.

Sand, C. 2010. Lapita calédonien. Archéologie d'un premier peuplement insulaire océanien. Paris: Société des Océanistes. doi.org/10.4000/books.sdo.1128.

Sand, C and S Bedford. 2010. Lapita: Ancêtres Océaniens/Oceanic ancestors. Paris: Musée du Quai Branly and Somogy Éditions d'Art.

Sillar, B and G Ramón Joffré. 2016. 'Using the present to interpret the past: The role of ethnographic studies in Andean archaeology'. World Archaeology 48 (5):656-673. doi.org/10.1080/00438243. 2016.1211033.

Siorat, J-P. 1990. 'A technological analysis of Lapita pottery decoration'. In Lapita design, form and composition: Proceedings of the Lapita design workshop, Canberra, Australia, edited by M Spriggs, 59-82. Canberra: Department of Prehistory, Research School of Pacific and Asian Studies, The Australian National University. 
Spriggs, M. 1984. 'Early coconut remains from the South Pacific'. Journal of the Polynesian Society 93:71-76.

Spriggs, M. 2003. 'Post-Lapita evolutions in Island Melanesia'. In Pacific Archaeology: Assessments and prospects, Proceedings of the International Conference for the 50th anniversary of the first Lapita excavation, Koné-Nouméa 2002, edited by C Sand, 205-212. Les Cahiers de l'Archéologie en Nouvelle-Calédonie 15. Nouméa: Département Archéologie, Service des Musées et du Patrimoine de Nouvelle-Calédonie. doi.org/10.4000/books.editionsmsh.2801.

Storey, AA, T Ladefoged and EA Matisoo-Smith. 2008. 'Counting your chickens: Density and distribution of chicken remains in archaeological sites of Oceania'. International Journal of Osteoarchaeology 18:240261. doi.org/10.1002/oa.947.

Summerhayes, GR, E Matisoo-Smith, H Mandui, J Allen, J Specht, N Hogg and S McPherson. 2010. 'Tamuarawai (EQS): An early Lapita site on Emirau, New Ireland, PNG'. Journal of Pacific Archaeology 1 (1):62-75.

Szabó, K. 2001. 'The reef, the beach, and the rocks: An environmental analysis of mollusc remains from Natunuku, Viti Levu, Fiji'. In The archaeology of Lapita dispersal in Oceania: Papers from the Fourth Lapita Conference, June 2000, Canberra, Australia, edited by G Clark, AJ Anderson and T Vunidilo, 159-166. Terra Australis 17. Canberra: Pandanus Books.

Szabó, K. 2009. 'Molluscan remains from Fiji'. In The early prehistory of Fiji, edited by G Clark and AJ Anderson, 183-211. Canberra: ANU E Press. doi.org/10.22459/TA31.12.2009.08.

Terrell, JE, and RL Welsch. 1997. 'Lapita and the temporal geography of prehistory'. Antiquity 71:548572. doi.org/10.1017/S0003598X0008532X.

Twiss, K. 2012. 'The archaeology of food and social diversity'. Journal of Archaeological Research 20 (4):357-395. doi.org/10.1007/s10814-012-9058-5.

Valentin, F, HR Buckley, E Herrscher, R Kinaston, S Bedford, M Spriggs, S Hawkins and K Neal. 2010. 'Lapita subsistence strategies and food consumption patterns in the community of Teouma (Efate, Vanuatu)'. Journal of Archaeological Science 37 (8):1820-1829. doi.org/10.1016/j.jas.2010.01.039.

van der Veen, M. 2003. 'When is food a luxury?' World Archaeology 34 (3):405-427. doi.org/10.1080/ 0043824021000026422 .

Walter, A and V Lebot. 2007. Gardens of Oceania. ACIAR Monograph no. 122. Canberra: Australian Centre for International Agricultural Research.

Walter, A and C Sam. 2002. Fruits of Oceania. Translated by P Ferrar. ACIAR Monograph no. 85. Canberra: Australian Centre for International Agricultural Research. Originally published as Fruits d'Océanie, Marseille: IRD Éditions.

Wiessner, P. 2012. 'Of feasting and value: Enga feasts in a historical perspective (Papua New Guinea)'. In Feasts: Archaeological and ethnographic perspectives on food, politics, and power, edited by M Dietler and B Hayden, 115-143. Tuscaloosa: University Alabama Press. doi.org/10.1525/ aa.2002.104.4.1236.

Worthy, TH and GC Clark. 2009. 'Bird, mammal and reptile remains'. In The early prehistory of Fiji, edited by GC Clark and AJ Anderson, 231-258. Terra Australis 31. Canberra: ANU E Press. doi.org/ 10.22459/TA31.12.2009.10.

Worthy, TH, S Hawkins, S Bedford and M Spriggs. 2015. 'Avifauna from the Teouma Lapita site, Efate Island, Vanuatu, including a new genus and species of megapode'. Pacific Science 69 (2):205-254. doi.org/10.2984/69.2.6. 
This text is taken from Archaeologies of Island Melanesia: Current approaches to landscapes, exchange and practice, edited by Mathieu Leclerc and James Flexner, published 2019 by ANU Press, The Australian National University, Canberra, Australia.

doi.org/10.22459/TA51.2019.12 